\title{
Pola Komunikasi Politik Partai Keadilan Sejahtera pada Kampanye Pemilu 2004 di Wilayah Jakarta Timur
}

\author{
Abdul Aziz* \\ STKIP Kusuma Negara, Indonesia
}

\begin{abstract}
Abstrak-Penelitian ini dilatar belakangi oleh DPD PKS Jakarta Timur yang berhasil memperoleh suara terbanyak di daerah Jakarta Timur. Penelitian ini menarik diteliti sebab partai ini memiliki perbedaan dengan partai lain. Bila Sebagian besar partaipartai lain menjual tokoh terkenal tingkat nasional untuk menarik dukungan masyarakat, maka PK Sejahtera lebih menjual programprogram partai dan isu-isu populis. Dalam memperkenalkan ke masyarakat DPD PKS Jakarta Timur mengunakan komunikasi politik yang baik. Dari latar belakang tersebut penelitian ini ingin mengetahui bagaiman proses komunikasi politik, siapa saja yang berperan, bagaimana pesan-pesan yang disampaikan, serta bagaimana saluran dan media komunikasi yang digunakan dalam kampanye. Penelitian ini menggunakan pendekatan kualitatif Metode pengumpulan data primer menggunakan wawancara mendalam terhadap infroman-informan kunci sebanyak 6 orang dan data-data sekunder. Hasil penelitian penelitian menunjukkan bahwa komunikasi yang diguanakan DPD PKS Jakarta Timur pada kampanye 2004 adalah komunikasi massa, komunikasi interpersonal. Proses komunikasi dilakukan oleh komunikator politik terdiri dari caleg, elit partai, aktivis partai dan tokoh masyarakat. Pesan utama yang disampaikan adalah "bersih" dan "lebih peduli". Media yang dipakai adalah media elektronik dan
\end{abstract} media cetak.

\author{
Kata kunci: \\ Kampanye, \\ Partai Politik, \\ Pemilu.
}

Histori:

Dikirim: 12 Maret 2021

Direvisi: 16 Maret 2021

Diterima: 17 Maret 2021

Online: 18 Maret 2021

\section{Identitas Artikel:}

Aziz, A. (2021). Pola Komunikasi Politik Partai Keadilan Sejahtera pada Kampanye Pemilu 2004 di Wilayah Jakarta Timur. Jurnal Citizenship Virtues, 1(1), 69-82.

\section{PENDAHULUAN}

Pemilu 2004 merupakan pemilu yang kedua sejak Orde Reformasi begulir. Setelah terlepas dari rezim otoriter Orde Baru, bangsa Indonesia mengalami masa transisi guna menata Kembali segi kehidupan disegala bidang. Transisi politik di Indonesia yang sudah berlangsung selama lebih dari lima tahun harus diakhiri. Bangsa Indonesia haruslah mulai untuk hidup normal tanpa terbelenggu dengan krisis-krisis yang ada selama ini. Krisis politik merupakan salah satu krisis yang belum terselesaikan. Pemilu 2004 diharapkan akan membawa Indonesia normal dalam kehidupan politik.

\footnotetext{
* Corresponding author

E-mail: abdul_aziz@stkipkusumanegara.ac.id
} 
Pemilu merupakan salah satu tolak ukur apakah sebuah negara itu dapat dikatakan demokratis. Dengan pemilu masyarakat akan dapat berpartisipasi untuk memilih pemimpin-pemimpinnya. Pemimpin-peminpin itu yang nantinya diharapakan akan menata kehidupan berbangsa dan bernegara kearah yang lebih baik. Demokrasi sendiri menurut Huntington, Marjohan \& Abadi (1995) mengandung pengertian secara sederhana sebagai suatu system politik dimana pembuat keputusan kolektif tertinggi dalam system itu dipilih melalui pemilihan umum yang adil, jujur, dan berkala. Pemilu yang adil untuk membentuk parlemen nasional merupakan landasan demokrasi dan merupakan Tindakan pembaharuan dan peneguhan kembali demokrasi dari waktu ke waktu (Meyer, 2003)

Melalui pemilu, partai politik dapat berebut kekuasaan secara damai, perbedaan kepentingasn yang beraneka ragam dapat diselesaikan melalui pemilu. Partai politik diberikan kesempatan untuk memperebutkan dukungan rakyat secara damai. Setiap partai politik diberikan kesempatan yang sama untuk berkampanye meraih dukungan rakyat. Dengan pemilu maka akan didapat siapa yang dipercaya rakyat dan berhak untuk duduk di pemerintahan maupun di lembaga legislative. Hasil pemilu merupakan jalan keluar dari konfilk politik antara partai-partai untuk memperebutkan posisi-posisi politik (Rauf, 2001)

Hasil pemilu 2004 menempatkan Partai Golkar pada posisi pertama. Pada pemilu 2004 ini Partai Golkar berhasil menggeser PDIP ke urutan kedua. PDIP pada pemilu 1999 merupakan partai pemenang pemilu. Pada Pemilu 2004 ini bila kita cermati dari perolehan suara partai-partai politik, ada beberapa partai yang menarik untuk menjadi sorotan, seprti partai demorat dan Partai Keadilan Sejahtera. Dalam perolehan suara, kedua partai ini memperoleh suara yang sangat signifikan. Partai Demokrat meskipun sebagai partai politik baru, telah dapat memperoleh dukungan yang luas dengan memperoleh 53 kursi di DPR. Sedangkan Partai Keadilan Sejahtera partai penerus Partai Keadilan pada pemilu 2004 ini memperoleh kursi 6 kali lipat dari perolehan kursi pada pemilu 1999 yaitu hanya 7 kursi saja.

Perolehan kursi Partai Demokrat yang relative banyak tersebut bisa disebabkan ketokohan Susilo Bambang Yudhoyono sebagai pencetus Partai Demokrat. Dalam pandangan masyarakat Indonesia ketokohan masih diagungkan, sehingga ketokohan masih menjadi faktor pengaruh yang kuat dari sebuah partai politik untuk memperoleh dukungan suara dari rakyat. Bila kita lihat dari 7 urutan teratas partai politik pada pemilu 2004, partai-partai tersebut masih mengandalkan tokoh dalam mendulang suara pemilih. Partai Golkar didalamnya banyak tokoh-tokoh telah dikenal luas oleh masyarakat, baik yang menjadi Menteri maupun anggota DPR pusat. Akbar Tanjung, sebagai ketua umum partai adalah tokoh yang cukup dikenal oleh masyarakat. Di Golkar masih ada Yusuf Kalla seorang Menteri dan pengusaha sukses. PDIP pada Pemilu 2004 dipimpin oleh Megawati yang pada waktu bersamaan masih menjadi Presiden. Ketokohan Megawati ini menjadi faktor penting dalam memperoleh suara pada pemilu 2004. Sedangkan partai-partai besar lainnya juga memiliki tokoh berpengaruh, seperti PPP dengan tokoh Hamzah Haz, PKB dengan ketokohan Gus Dur, dan PAN dengan ketokohan Amien Rais. Sedangkan PKS sedikit berbeda, karena partai ini tidak memiliki tokoh sekaliber partai-partai besar lainnya. Tokoh yang dikenal luas mungkin hanya Nurmahmudi Ismail, Presiden pertama Partai Keadilan. Dia pernah menjabat Menteri pada Kabinet Gus Dur, itupun tidak lebih dari 2 tahun, sehingga belum begitu dikenal secara luas oleh masyarakat. Jadi bisa dikatakan PKS tidak memiliki tokoh terkenal. 
Tokoh PKS banyak bergerak dalam bidang Pendidikan dan dakwah Islam dan dikenal baru tingkat wilayah, belum secara nasional.

Pada penyelengaraan Pemilu legisltaif 2004 di wilayah DKI Jakarta PKS memperoleh 18 Kursi di DPRD Propinsi DKI Jakarta. Perolehan sebanyak 18 kursi ini sangatlah menakjubkan, sebab bila dilihat perolehan pada pemilu 1999 PKS yang pada saat itu bernama Partai Keadilan hanya memperoleh 4 kursi di DPRD DKI Jakarta (KPUD Jakarta,2004). Perolehan 18 kursi ini tersebar di lima wilayah Jakarta. Wilayah Jakarta Timur memperoleh kursi terbanyak 6 kursi, Jakarta Selatan memperoleh 4 kursi, Jakarta Barat memperoleh 4 kursi, wilayah Jakarta utara dan kepulauan seribu memperoleh 2 kursi, dan wilayah Jakarta Pusat memperoleh 2 kursi. Dapat dilihat DPD PKS Jakarta Timur menjadi penyumbang terbanyak untuk DPRD DKI Jakarta, yakni sebanyak 6 Kursi.

Peroleh suara PKS Jakarta Timur pada pemilu 2004 ini mengalami kenaikan yang cukup besar, dibanding dengan pemilu 1999. Dalam pemilu 1999 PK (Sejahtera) memperoleh 77.086 Suara, sedangkan Pemilu 2004 mengalami kenaikan empat kali lipat menjadi 305.233 suara. PKS Jakarta Timur sedikit berbeda dengan partai-partai lainnya. Bila Sebagian besar partai-partai lain menjual tokoh terkenal, maka PKS Jakarta Tikur lebih menjual program-program partai dan isu-isu populis saja. Kader-kader PKS relative masih muda, dan orang-orang baru dalam dunia politik. Diharapkan dengan menampilkan program-program partai dan isu-isu populis tersebut dapat menarik dukungan massa.

Dalam proses berlangsungnya kampanye, PKS Jakarta Timur melakukan komunikasi politik sebagai salah satu cara meyakinkan massa. Diharapkan dengan komunikasi politik, massa terpengaruh untuk memilih PKS pada pemilu 2004. Keberhasilan proses komunikasi politik PKS Jakarta Timur pada saat kampanye Pemilu 2004 ini disebabkan oleh komunikator politik, pesan, dan media yang dikemas dengan baik.

Komunikator politik adalah orang bertugas untuk menyampaikanpesan-pesan politik kepada calon pemilih. Para komuniktor politik yang ada di PKS Jakarta Timur antara lain calon legislative, elit partai, aktivis dan tokoh masyarakat. Pesan politik atau isu politik yang disampaikan tidak dikemas dalam nuansa Islam yang kental. Tidak ada pesan akan menerapkan syariat Islam, tetapi lebih mengedepankan perbaikan rakyat dan penegakan supremasi hukum, seperti pemnberantsan KKN, menghapus ketidak adilan, dan pengentasan kemiskinan. Media yang digunakan adalah media cetak dan elektronik, dengan melalui komunikasi massa, maupun komunikasi interpersonal.

Rumusan masalah pada penelitian ini adalah bagaimana proses komunikasi politk yang digunakan oleh PKS, siapa komunikator dan bagaimana komuniktor itu melakukan komunikasi, bagaimana pesan-pesan yang disampaikan dalam kampanye, bagaimana saluran dan media komunikasi yang digunakan dalam kampanye. Tujuan dari penelitan ini adalah untuk menjelaskan pola komunikasi Politik PKS pada kampanye Pemilu 2004 di wilayah Jakarta Timur, sehingga kita dapat mengetahui dan bisa dijadikan contoh bagi khalayak luas.

\section{Kampanye Partai Politik}

Kampanye pada pemilihan umum akan mejadi sebuah ajang berlangsungnya proses komunikasi politik. Proses komunikasi politik ini dilakukan oleh peserta kampanye. Kampanye dijadikan sarana setiap peserta untuk mempengaruhi para pemilih, 
supaya mau memilih partainya. Kampanye didefrinisikan sebagai serangkaian Tindakan komunikasi yang terencana dengan tujuan menciptakan efek tertentu pada sejumlah besar khalayak yang dilakukan secara berkelanjutan pada kurun waktu tertentu. (Roger dan Storey, 1987).

Kegiatan kampanye memiliki tiga dimensi. Pertama, dimensi dagang, setiap kegiatan. Sebagaimana kegiatan berdagang, maka peserta kampanye harus pandai mengkemas tema yang dibawakan secantik mungkin, sehingga menarik perhatian pemberi suara untuk membeli. Kedua, dimensi komunikasi politik, kampanye menuntut adanya kesesuaian antara persepsi komunikator dan komunikan. Ketiga dimensi mobilisasi, sebagai kegiatan mobilisasi, kampanye berhubungan dengan ikatan psikologis pemberi suara dengan partai politik (Imawan, 1997). Sedangkan Teknik kampanye menurut Imawan (1997), dalam ilmu politik ada empat Teknik kampanye yaitu:

a. Kampanye dari pintu ke pintu (door to door campaign) dilakukan dengan cara kandidat mendatangi langsung para pemilih, sambil menanyakan langsung persoalan-persoalan yang mereka hadapi, disini terjadi hubungan langsung antar kandidat dengan calon pemilih. Teknik ini menjamin adanya keseuaian persepsi antara si pemilih (komunikan) dengan calon yang dipilih (komunikator)

b. Diskusi kelompok (group discussion) dilakuakan dengan membentuk kelmpokkelompok diskusi kecil yang membicaarakan masalah-masalah yang dihadapi masyarakat. Teknik ini memungkinkan anggota masyarakat terlibat langsung dengan persoalan dan usaha-usaha memecahkan persoalan masyarakat yang ada Bersama calon mereka. Disini tercipta tukar-menukar pandangan secara intensif dan dapat pula menumbuhkan solidaritas kelompok.

c. Kampanye massa tak langsung, (indirect mass campaign) dilakukan dengan cara berpidato di radio, televisi, atau memasang iklan dimedia cetak, mesang spanduk balio di tempat tempat strategis.

d. Kampanye massa langsung (direct mass campaign) dilakukan dengan cara melakukan aktivitas yang dapat menarik perhatian massa, seperti pawai, rapat akbar, pertunjukan kesenian.

Faktor-faktor yang secara nyata memberikan kontribusi pada keberhasilan kampanye menurut Venus (2004), meliputi:

a. Peran media massa. Media massa dianggap sangat fektif dalam menciptakan kesadarn, meningkatkan pengetahuan dan mendorong khalayak berpartisipasi dalam proses kampanye.

b. Peran komunikasi antar pribadi. Bentuk komunikasi ini, khusunya yang dilakukan lewat kelompok teman sebaya (peer-group) dan jaringan social, dipandang sebagai intrumen penting dalam menciptakan perubahan perilaku dan memelihara kelanggengan perubahan tersebut.

c. Karakter sumber dan media. Kredibilitas sumber memberikan kontribusi yang besar bagi pencapaian tujuan kampanye. Demikian pula halnya dengan pemanfaatan media komunikasi yang tepat yang sejalan dengan kebiasaan bermedia (media habit) khalayak.

d. Himbuan pesan. Dalam hal ini pesan harus dirancang secara spesifik agar mampu menghimbau nilai-nilai individual.

e. Kesesuaian waktu, aksebilitas dan kecocokan, agar menjadi efektif pesan-pesan kampanye harus disampaikan pada saat yang tepat, budaya yang sesuai, dan melalui media yang tersedia dilingkungan khalayak. 


\section{Komunikasi Politik}

Komunikasi adalah pengalihan informasi untuk memperoleh tanggapan. Komunikasi dapat digunakan seseorang untuk mempengaruhi atau berusaha mempengaruhi perilaku, keyakinan sikap orang lain. (Aranguren, 1967). Adapun komponen komunikasi bila mengaju kepada paradigma Harold Lasswel "who says what channel to whom with what effect" (siapa mengatakan apa melalui saluran apa kepada siapa dengan efek apa), maka komponen komunikasi politik terdiri dari Komunikator politik, pesan politik, media komunikasi politik, khalayak (komunikan) politik, dan efek.

\section{Komunikator Politik}

Komunikator politik adalah orang atau sebuah kelompok yang mengeluarkan informasi atau Tindakan sebagai sumber informasi (pesan). Semua orang dapat menjadi seorang komunikasi politk. Schramm (1955) memberikan fungsi kepada komunikator dan komunikan, dimana fungsi harus cocok antara komuniktor dan komunikan, sehingga komunikasi berjalan harmonis. Komunikator melakukan penerangan komunikan menjadi mengerti. Komunikator melakukan Pendidikan, komunikan bersedia belajar.

Untuk memahami komunikasi politik, maka perlu diidentifikasi, siapa saja yang biasa menjadi komunikator politik. Komunikator politik dapat dibagi tiga jenis. Pertama, politikus, politikus adalah orang mencari pengaruh dari komunikasi, politikus utama yang bertindak bertindak sebagai komunikator politik adalah pemegang jabatan pemerintahan, legislatif, yudikatif, maupun diluar itu, yaitu para kandidat pejabat, pemimpin partai, baik tingkat nasional maupun tingkat local. Komunikasi politik digunakan untuk merebut atau mempertahankan jabatannya. Kedua, Profesional, professional adalah orang yang bekerja dalam bidang komunikasi. Komunikator professional adalah seorang makelar symbol, orang yang mnerjemahkan sikap, pengetahuan, dan minat suatu komunitas Bahasa ke dalam istilah-istilah komunikasi bahasa yang lain yang berbeda tetapi menarik dan dapat dimengerti. Komunikator profesional adalah manipulator dan makelar symbol yang menghubungkan para pemimpin dengan para pengikutnya. Ada dua jenis komunikator professional. Pertama adalah jurnalis. Kedua adalah promotor, yakni seperti manajer kampanye dan pengarah publisitas kandidat politik. Keduanya memiliki perbedaan. Bila jurnalis tidak memihak kepada siapun maka promotor memihak kepada yang membayar. Komunikator ketiga adalah Aktifis. Komunikator politik ini ada dua jenis, pertama, juru bicara, yaitu orang yang menjadi juru bicara bagi kepentingan kelompok yang terorganisir, kedua, pemuka pendapat, yaitu orang yang dimintai petunjuk dan informasi. (Leonard W Doob. 2004)

Komunikasi politik yang digunakan dalam sebuah kampanye pemilu, unsur persuasif sangat mempengaruhi. Persuasif adalah cara mengubah sikap dan perilaku orang dengan menggunakan kata-kata lisan dan tertulis, persuasi adalah proses menanamkan opini baru, persuasi berusaha untuk mengubah sikap, kepercayaan, atau perilaku sesorang. Untuk keberhasilan komunikasi persuasif komunikator politik harus memiliki prinsip, antara lain:

Status Komuniktor, Status adalah peran yang melekat pada komunikator tersebut dalam kehidupan sehari-hari sperti guru, mahasiswa, dokter, dan 
sebagainya. Makin tinggi status, semakin besar kemungkinan komuniktor itu untuk bersifat persuasif.

Kredibilitas Komunikator, komunikator dianggap memiliki keahlian dan keandalan. Smakin kredibel seorang komunikator, maka akan semakin efektif persuasinya. Daya Tarik komunikator, daya Tarik komunikator dapat berupa latar belakngnya, kepribadian dari komuniktor tersebut. Komuniktor itu memiliki daya Tarik, bisa dengan adanya homofili, yakni kesamaan usia dan latar belakang yang sama dengan komunikan (Effendy, 1986)

Ada beberapa teknik yang bisa digunakan oleh komunikator dalam komunikasi, pertama, Teknik asosiasi, Teknik asosisasi adalah penyajian pesan komunikasi dengan menumpangkan pada suatu objek atau peristiwa yang menarik perhatian khalayak. Kedua Teknik integrasi, ialah kemampuan komunuikator untuk menyatukan diri secara komunikatif dengan komunikan, dengan melaluikata-kata verbal atau nirverbal, komunikator menggambarkan bahwa seorang komunikator merasa senasib, sehingga dapat dikatakan menjadi satu dengan komunikan. Kata yang digunakan seperti "kita" bukan "saya" atau "kami". kata kita mengandung makna komunikator Bersama komunikan. Bahwa komunikator tidak hanya memperjuangkan kepentingan sendiri, tetapi juga memperjuangkan kepentingan komunikan. Ketiga, Teknik ganjaran, adalah kegiatan untuk mempengaruhi orang lain dengan cara mengiming-iming hal yang menguntungkan atau menjanjikan harapan. Dalam kampanye politik bisa diambil contoh" bila anda memilih partai A, maka akan hidup sejahter. Keempat, Teknik tataan, adalah upaya Menyusun pesan komunikasi sedemikian rupa, sehingga enak didengar atau dibaca serta termotivas untuk melakukan sebagaimana disarankan oleh pesan tersebut (Effendy, 1986).

\section{Pesan}

Dalam komunikasi seorang komunikan akan "mengatakan apa", mengatakan apa inilah yang disebut pesan, pesan adalah gagasan atau ide, pesan dapat berupa lambang, symbol, Bahasa, gambar, lukisan, foto, film, gerak tubuh, ekpresi wajah, dan segala Tindakan (Nimmo, 2004). Menurut Roger \& Storey (1987), pesan-pesan kampanye dirancang secara segmentatif sesuai dengan jenis-jenis khalayak yang dihadapi. Segmentasi tersebut dapat berdasarkan usia, jenis kelamin, pekerjaan dan budaya.

Pesan amatlah penting dalam sebuah komunikasi. Untuk membuat pesan tersebut menghasilkan efek. Supaya komunikasi menjadi sukses, sebuah pesan, Pertama, harus dirancangkan dan disampaikan sedemikian rupa sehingga dapat menarik perhatian sasaran yang dimaksud. Kedua, pesan harus menggunakan tanda-tanda yang tertuju kepada pengalaman yang sama antara komunikator dan komunikan, sehingga sama-sama dapat mengerti. Ketiga, pesan harus membangkitkan kebutuhan pribadi komunikan. Keempat, pesan harus menyarankan suatu cara untuk memperoleh kebutuhan tadi yang layak bagi situasi kelompok tempat komunikan berada pada saat ia digerakkan untuk memberikan tanggapan yang dikehendaki (Schramm, 1955).

\section{Media}

Untuk menyampaikan pesan kepada komunikan, seorang komunikator memerlukan Alat media. Media adalah sarana yang memudahkan penyampaian pesan. Alat komunikasi adalah untuk melancarkan saling tukar pesan (Nimmo, 2004). 
Komunikasi bermedia dapat melalui komunikasi masaa, komunikasi massa menekankan komunikasi satu-kepada-banyak. Dalam proses ini jumlah komunikannya besar, heterogen, dan anomin. Pesannya bersifat umum, untuk berbagai kalangan. Media yang digunakan adalah media elektronik dan media cetak. Efek yang ditimbulkan tergantung dengan pengemasan pesan yang dibentuk. Dalam penggunaan pada komunikasi massa, bisa menggunakan media elektronik dan media cetak. Media elektronik antara lain, radio, televisi, internet, DVD. Sedangkan media cetak adalah, surat kabar, poster, brosur, sticker, spanduk.

\section{Saluran Komunikasi}

Dalam konteks organisasi, arus komunikasi mengalir secara formal mengikuti saluran formal sesuai dengan struktur organisasi. Secara tradisional, ada tiga arah utama arus pesan dan informasi mengalir lewat saluran formal yaitu: Pertama, arus saluran komunikasi formal ke bawah. Kedua, arus komunikasi vertical ke atas. Ketiga, arus saluran komunikasi formal horizontal. Ada saluran secara tidak diakui, yakni arus saluran komunikasi informal (Corbett, 1989). Dalam saluran komunikasi formal vertical ke bawah ini, arus pesan dan infromasi berasal dari unsur pimpinan organisasi mengalir ke seluruh lapisan struktur organisasi di bawah. Dalam partai politik aliran pesan dan informasi berasal dari atas ke bawah. Dapat berasal dari pimpinan partai maupun dari struktur politik diatas kepada struktur politik di bawah. Sedangkan arus saluran komunikasi keatas adalah saluran komunikasi yang mengalir dari bawah ke atas. Pesan pada saluaran ini adalah usulan, saran, dan tutntutan dari bawah kepada pimpinan atau struktur organisasi di atas (Effendy, 1986).

Komunikasi melalui saluran diatas dapat dilakukan melalui komunikasi massa dengan media maupun melalui komunikasi interpersonal (tatap muka). Komunikasi interpersonal ini didefinisikan sebagai proses pengiriman dan penerimaan pesanpesan anatar dua orang, atau diantara sekelompok kecil orang-orang, dengan beberapa efek dan beberapa umpan balik seketika. Dialogis adalah bentuk komunikasi antarpribadi dengan menunjukkan terjadi interaksi. Komunikasi antarpribadi dinilai paling ampuh dalam kegiatan mengubah sikap, kepercayaan, opini, dan perilaku komunikan. Komunikasi interpersonal ini sering digunakan dalam komunikasi persuasi. Komunikasi ini biasanya digunakan kepada komunikan yang memiliki potensial saja, seperti tokoh masyarakat yang memilikii pengikut banyak. Jika tokoh maysrakat itu dapat diubah sikap dan idiologinya, maka seluruh pengikutnya akan berubah juga sikap dan idiologinya (Effendy, 1986).

\section{METODE PENELITIAN}

Studi ini menggunakan pendekatan kualitatif yakni penelitian dengan cara melakukan wawancara mendalam (indepth interview). Penelitian ini dengan sengaja memilih informan dan dokumen atau bahan-bahan visual yang dapat memberikan jawaban terbaik dari pertanyaan penelitian (Creswell \& Creswell, 2017). Penulisan penelitian ini bersifat deskriptif analisis. Metode deskriptif adalah metode dalam meneliti status kelompok manusia, suatu objek, suatu set kondisi, suatu sistem pemikiran ataupun suatu kelas peristiwa pada masa sekarang. Tujuan dari penelitian deskriptif ini adalah untuk membuat deskriptif, gambaran atau 
lukisan secara sistematis, factual dan akurat mengenai fakta-fakta, sifat-sifat serta hubungan antar fenomena yang diselidiki (Moh Nazir, 1988).

Teknik pengumpulan data, dimana data adalah segala keterangan (informasi) mengenai segala hal yang berkaitan dengan tujuan penelitian. Data (informasi) digunakan sebagai bahan analisis terhadap objek atau permasalahan yang akan diteliti. Penelitian ini menggunakan dua sumber data, yaitu data primer dan data sekunder. Data primer diperoleh dengan cara penelusuran wawancara mendalam dengan narasumber. Sedangkan data sekunder diperoleh melalui studi kepustakaan, yakni dengan mengumpulkan data dari buku-buku, jurnal, majalah, dan surat kabar yang berkaitan dengan penelitian ini.

Subjek penelitan ini ada dua. Pertama, mengenai konsep pola komunikasi politik, yang dimaksud penulis adalah konsep dari komunikator, media, pesan, komunikan dilakukan pika PKS Jakarta Timur dalam menghadapi pemilu 2004. Kedua, PKS Jakarta Timur Struktur DPD (Dewan Pimpinan Daerah), beserta dengan anggota ke bawah.

\section{HASIL DAN PEMBAHASAN Jenis Komunikator Politik}

Pada kampanye Pemilu 2004 komunikator politik DPD PKS Jakrta Timur ini dapat digolongkan menjadi dua. Pertama jurkam (juru kampanye), yakni jkomunikator yang politik yang berkampanye sesuai dengan jadwal yang dikeluarkan oleh KPUD. Kedua komunikator politik yang tidak menjadi jurkam, mereka melakukan tugas sebagai komunikator secara individu dan tidak terpaku dengan jadwal kampanye. Komunikator non jurkam ini terdiri dari para kader partai, mulai dari para aktivis sampai para pengurs partai. Pada pemilu 2004 DPD PKS Jakarta Timur Menyusun dan memilih para jurkam untuk ditugaskan dalam kampanye sebanyak 268 orang. Menurut M. Fardan Prasetyo, ketua pengembangan publik, jurkam merupakan suatu yang penting, karena para jurkam merupakan ujung tombak dalam mengkomunikasikan isu partai. Dalam penyampaian pesan partai tidak hanya merupakan tugas para jurkam yang ada di daftar dan pada saat kampanye saja, tetapi tugas semua kader mulai dari jajaran pengurus hingga aktivis partai. Merujuk teori Doob (1971), komunikator dapat dibagi tiga jenis, yakni politikus, professional, dan aktivis. Dari penelitian pada studi ini, orang-orang yang dipercaya DPD PKS Jakarta Timut untuk menjadi komunikator politik adalah para caleg, elit partai, aktivis partai, dan tokoh masyarakat, Caleg dan elit partai dapat digolongkan ke dalam politikus, sedangkan aktivis partai dan tokoh masyarakat digolongkan ke dalam aktivis. Jenis komunikator yang tidak ada di DPD PKS Jakarta Timur adalah professional.

\section{Calon Legislatif (Caleg)}

Caleg merupakan seorang komunikasi politik. Dalam hal ini caleg yang dimaksud adalah caleg PKS Jakarta Timur untuk DPRD Jakarta. Mereka merupakan politisi yang meperjuangkan kepentingan partai. Pemilihan caleg di PKS untuk seluruh tingkatan, berbeda dengan partai politik lain. Dalam memilih caleg, PKS menyelenggarakan pemilihan umum internal (PUI). Para caleg ini dipilih oleh kader-kader partai, jadi bukan kebiajakan pengurus partai dalam menentukan caleg. Partai hanya mengesahkan dan mendaftarkan ke KPU atau KPUD para caleg yang 
telah dipilih oleh para kader. Dari Jakarta Timur ada 22 caleg untuk DPRD Jakarta, terditi dari 15 laki-laki dan 7 perempuan.

\section{Elit Partai}

Elit partai, yaitu para pengurus DPD, DPC, dan DPRa. Arus komunikasi yang terjadi pada elit ini dapat menggunakan beberapa bentuk. Dalam komunikasi internal organisasi para elit PKS Jakarta Timur menggunakan saluran komunikasi vertical keatas dan vertical ke bawah. Menurut M. Fardan Prasetyo Untuk komunikasi kepada eksternal yakni masyarakat, para elit partai menggunakan saluran horizontal sesuai dengan kebijakan partai, bahwa seluruh elemen partai diwajibkan untuk memperkenalkan partai kepada masyarakat, maka elit partai ikut berperan dalam proses memperkenalkan partai kepada masyarakat. Baik dengan menjadi jurkam maupun pendekatan dan komunikasi interpersonal ke tokoh-tokoh masyarakat. Dalam melakukan pendekatan dan komunikasi interpersonal kepada tokoh-tokoh masyarakat di daerah Jakarta Timur, terlebih dahulu pihak partai membuat prospek tokoh mana yang akan didekati oleh elit-elit partai. Tokoh masyarakat yang dianggap memiliki pengaruh dan basis massa didatangi secara khusus.

\section{Aktivis Partai}

Para aktivis partai ini merupakan kader dan simpatisan yang secara sukarela melakukan komunikasi politik kepada masyarakat. Para aktivis partai ini sukarela melakukan komunikasi politik kepada masyarakat. Para aktivis partai ini memiliki semangat yang tinggi dalam memperkenalkan PKS. Kader dan simpatisan melakukan komunikasi disetaip kesempatan, dimana saja dan kepada siapa saja. Begitu yang diutarakan oleh Awal Bekari (Sekretaris umum DPD PKS Jakarta Timur). Komunikasi politik yang dilakukan oleh para aktivis partai ini lebih di kenal dengan direct selling. DPD PKS Jakarta Timur mempersiapkan 5000 kader untuk melakukan direct selling. Komunikasi ini termasuk komunikasi interpersonal dan dapat digolongkan ke dalam saluran komunikasi komunikasi informal, dimana para kativis bukan bagian dari struktur ornagisasi PKS.

\section{Tokoh Masyarakat (Eksternal Partai)}

Menurut Zulkikifli AS, tokoh Eksternal partai ini merupakan orang-orang yang telah dipilih oleh pihak partai untuk ikut mengkampanyekan PKS pada pemilu 2004. Tokoh eksternal ini menjadi jurkam pada saat PKS menggelar kampanye. Tokoh eksternal ini adalah tokoh-tokoh yang menjadi simpatisan PKS. Tokoh ini dipilih karena memiliki pengeruh yang kuat di masyarakat. Pihak partai mendatangi secara khusus untuk meminta kesediaan para tokoh masyarakat menjadi jurkam. Komunikasi yang dilakukan oleh para tokoh masyarakat kepada masyarakat luas ini menggunakan saluran informal dimana keberdaan individu tokoh masyarakat ini bukan bagian dari struktur organisasi

\section{Kriteria Komunikator Politik}

DPD PKS Jakarta Timur tidak mengeluarkan kebijakan khusus mengenai kriteria komunikator politik, tetapi partai mengariskan bahwa seorang jurkam harus memiliki kredibilitas dan kepribadian yang baik. Sifat ini sesuai denga napa yang dikatakan oleh Nimmo (2004), bahwa untuk keberhasilan komunikasi persuasif 
(mempengaruhi), maka komunikator harus memiliki status (pekerjaan/latar belakang), kredibilitas, dan daya tarik yang baik, makin baik status, kredibilitas, dan daya tarik, maka akan lebih berhasil dalam proses mempengaruhi.

\section{Status Komunikator Politik}

Status yang dimaksud adalah pekerjaan dari para komunikator politik tersebut. Menurut Zulkifli AS dalam memilih jurkam tidak ditentukan latar belakang pekerjaannya. Pemilihan juga tidak dikhususkan kepada kelompok tertentu saja. Hal ini dimaksudkan agar partai memiliki jurkam yang beragam. Dalam penyampaian pesan kampanye, jurkam dapat menyampaikan pesan yang sesuai dengan latar belakang pekerjaannya, dengan demikian para jurkam benar-benar menguasai tema tersebut sehingga masyarakat akan lebih percaya, karena orang yang menyampaiakan pesan adalah orang yang kompeten terhadap isu tersebut. Secara umum menurut Awal Bekari dan dilihat dari daftar Jurkan DPP PKS Jakarta Timur, pekerjaan para jurkam ini berasal dari berbagai kalangan, seperti Mahasiswa, pendidik, dokter, karyawan, wirausaha dan ustadz. Dari teori Nimmo (2004), Bisa dianalisis bahwa status dari para komunikator politik PKS Jakarta Timur memiliki status yang baik. Para komunikator politik memiliki pekerjaan yang bisa dikatakan berbobot bagi ukuran masyarakat Jakarta Timur.

\section{Kredibilitas Komunikator Politik}

Kredibiltas komunikator politik khususnya jurkam ini sangat penting. Apakah jurkam (caleg) dari partai tersebut benar-benar akan memegang janji yang diucapkan pada saat kampanye. Untuk membuktikan kredibilitas dari jurkam atau para caleg teresebut maka perlu dilihat ke belakang mengenai riwayat kehidupan jurkam tersebut. Seperti kemasmpuan, pengalaman, dan juga apakh memiliki prospek kedepan atau semangat berjuang untuk perubahan. Mengenai kredibilitas para jurkam, menurut Muhammad ketua I DPD PKS Jakarta Timur, bahwa para jurkam itu merupakan para tokoh di daerahnya. Masyarakat sudah menilai bahwa mereka adalah orang terbaik secara kualitas individual, secara khlak, dan secara pemikiran. Mereka adalah orang-orang yang biasa bertablik, berceramah di masyarakat, sehingga secara komunikasi dengan masyarakat sudah tidak ada masalah. Kredibilitas komunikator PKS ini memenuhi persyaratan yang diajukan oleh Nimmo (2004), Rice \& Atkin (2012) untuk keberhasilan komunikasi politik.

\section{Daya Tarik Komunikator Politik}

Daya Tarik komunikator khususnya jurkam adalah memiliki kepribadian yang baik. Kepribadian itu bisa dicerminkan dari ketokohan jurkam tersebut. Zulkifli AS mengatakan bahwa daya Tarik dari para jurkam ini adalah kepribadian jurkam tersebut dan para jurkam tersebut dikenal dimasyarakat. Pihak partai sebelumnya melihat dahulu dalam memilih jurkam tersebut. Ketika individu tersebut dilihat mempunyai pengaruh di masyarakat maka individu tersebut ditunjuk untuk menjadi jurkam. Kemampuan berbicara juga menjadi penekanan dalam permilihan jurkam. Sedangkan menurut Muhammad daya Tarik dari para jurkam ini adalah pertama, mereka masih muda-muda, itu menjadi daya Tarik tersendiri bagi masyarakat, kedua, para jurkam ini didaerah masing-masing menjadi sebuah panutan. Para jurkam ini menjadi tempat bertanya bagi masyarakat mengenai berbagai masalah. Hal ini yang menyebabakan masyarakat mau dating ke tempat kampanye. 
Dalam proses komunikasi massa maupun interpersonal sifat homofili (kesamaan usia dan latar belakang antara komunikator dan komunikan) menurut Nimmo (2004) menjadi penting. Hal ini juga menjadi perhatian dari DPD PKS Jakarta Timur dalam menentukan jurkam. Menurut Zulkifli AS, dalam kampanye PK Sejahtera selalu menampilkan tokoh dari komunitas setempat sebagai jurkam. Dengan menampilkan tokoh setempat, maka pesan partai akan lebih dapat didengar oleh masyarakat. Dalam komunikasi interpersonal sifat homofilli juga berlaku, seorang kader memilih target yang sesuai dengan latar belakang dengan dirinya, seperti teman sekolah, teman kantor, dan orang-orang dilingkungan rumahnya.

\section{Pesan dan Teknik Penyampaian Pesan oleh Komunikator Politik \\ Pesan}

Pesan kampanye atau orang lebih mengenal dengan janji kampanye merupakan sebuah sarana pengenalan dan daya tarik bagi masyarakat untuk memilih sebuah partai. Menurut Schramm (1955), agar sebuah kampanye pemilu menghasilkan daya pengaruh yang besar, maka pesan-pesan itu dikemas dengan baik. Pesan harus juga membangkitkan kebutuhan pribadi komunikan/pemilih. Pesan utama PKS pada Pemilu 2004 adalah "Bersih dan Lebih Peduli". Citra bersih yang dibawa PKS ini telah diperlihatkan para anggota DPR/DPRD pada periode 1999-2004. Seluruh anggota dewan tidak terlibat KKN. Kader PKS telah menyelamatkan uang negara senilai total Rp. 739,6 miliar (Berry \& Waluyo, 2005). Citra bersih inilah yang selalu dikampanyekan dalam pemilu 2004. Selain pesan "Bersih" pesan utama yang di bawa oleh PKS adalah "Lebih Peduli" pesan ini merupakan sifat dari kepedulian terhadap masyarakat. Pesan lebih peduli ini telah diperlihatkan dari kerja kongkrit PK Sejahtera kepada masyarakat yang memerlukan bantuan. Menurut Awal Bekari kepedulian PKS ini dapat dilihat membantu korban bencana-bencana, baik itu banjir, tanah longsor, kebakaran, gempa bumi, dan bencana-bencan yang lain. Bila tidak terjadi bencana. PKS tetap peduli terhadap rakyat, dengan melakukan bakti social, seperti pengobatan gratis, bazar murah, dan sunatan masal. Pada saat ini masyarakat membutuhkan partai politk yang bersih dan peduli terhadap masyarakat. Bila dilihat dari dokumen PKS Jakarta Timur selain ada pesan utama, ada sekitar 25 pesan lain yang merupakan penjabaran dari pesan utama. Pesan tersbut dibagi menjadi bidang ekonomi, bidang Kesehatan, bidang penataan kota, bidang pendidikan, dan bidang keamanan.

Berdasarkan Teori Roger \& Storey (dalam Kusumarasri, Pradekso \& Ulfa, 2013) bahwa pesan-pesan kampanye harus dirancang secara segmentastif, hal ini dikuatkan oleh M Farhan Prasetyo, dia mengatakan bahwa ada perbedaan pesan di satu daerah dengan daerah lain, seperti daerah industry, maka pesan yang disampaikan lebih ditekankan pada memperjuangkan nasib buruh, dalam menyampaikan pesan komunikator melihat dulu konstituen yang akan menjadi pendengar. Bila berbicara dilingkungan pelajar, maka penyampaiaannya bersifat konsepsional, sedangkan bila berbicara pada masyarakat awan, maka pokok pembicaraan yang praktis-praktis saja.

\section{Penyampaian pesan oleh komunikator}

Menurut Effendy (1986) cara penyampaian pesan bisa melalui komunikasi massa maupun komunikasi interpersonal. Dalam komunikasi masa dapat dilakukan dengan 
Pertama, teknik asosiasi, yakni Teknik dimana penyajian pesan komunikasi dengan cara menumpangkan pada suatu objek atau peristiwa yang sedang menarik perhatian khalayak. Menurut Zulkifli AS pada kampanye 2004 PKS Jakarta timur menyampaikan pesan seperti pemberantasan korupsi, nasib buruh, dan tuntutan harga barang pokok yang murah. Isu-isu itu menjadi isu yang yang dijanjikan akan diperjuangkan.

Kedua, teknik integrasi ialah kemampuan komunikator untuk menyatukan diri secara komunikatif dengan komunikan, dengan melalui kat-kata verbal atu nirverbal. Menurut Emma Ruchaemah (salah satu Jurkam) Setiap jurkam berintegrasi dengan masyarakat umum yaitu menggunakan kata "kita" dan "saudara', bukan kata-kata "saya", "kalian". Kata kita dan saudara lebih memiliki sifat persamaan atau kesatuan antara jurkam dengan masyarakat. Kata-kata ini mengandung persamaan nasib antara jurkam dan masyarakat. Orasi jurkam yang disediakan dalam bentuk tulisan oleh pihak DPD PKS Jakarta timur memuat hal itu semua.

Ketiga ada teknik ganjaran. Teknik ini adalah kegiatan mempengartuhi orang dengan cara mengiming-imingi hal yang menguntungkan atau menjanjikan harapan. Seperti pemberian harapan bila memilih PKS maka PKS akan memperjuangkan perbaikan saran lingkungan, pemberatasan $\mathrm{KKN}$, dan pemberdayaan ekonomi, dan memperjuangkan murahnya harga-harga barang pokok. Cara komunikasi ini sangat eketif, karena didukung oleh kenyataan PKS selama ini telah banyak melakukan kerja nyata yaitu membantu warga yang terkena musibah, mengadakan pengobatan gratis, dan bakti social. Ini semua dilakukan untuk membuktikan bahwa PKS benar-benar memperhatikan dan peduli kepada masayarakat. Menurut Awal Bekari DPD PKS memang menganjurkan DPC samapi ranting untuk selalu melakukan bakti social, bazar, pengobatan gratis, dan membantu warga yang terkena musibah setiap waktu, tidak hany pada masa kampanye.

Keempat adalah teknik tataan, di mana komunikator menggunakan bahasa yang lugas. Bahasanya ditata dengan rapi sehingga mudah dicerna dan dapat mempengaruhi pemilih. Menurut M. Fardan Prasetyo bisa berupa lagu-lagu dengan syair yang membangkitkan perjuangan dan juga kalimat kalimat slogan.

Selain komunikasi massa DPD PKS Jakarta Timur dalam kampanye juga melakukan komunikasi interpersonal. Menurut Roger dan storey, untuk keberhasilan kampanye selain dilakukan komunikasi massa melalui media dan kepada orang banyak dilapangan harus disertai juga penyebaran personel kampanye untuk menindak lanjuti secara interpersonal. interpersonal adalah komunikasi yang langsung dilakukan kepada calon pemilih. Imawan (1997), menyebut ini adalah kampanye door to door. Imawan (1997) menambahkan bahwa dimensi kampanye itu adalah berdagang. Bagaimana barang dagangan itu bisa laku terjual. Barang dagangan itu adalah PKS. DPD PKS Jakarta Timur melakukan komunikasi interpersonal dalam memperkenalkan PKS adalah dengan metode direct selling atau direct marketing, yaitu cara pemasaran produk, dalam hal ini produknya adalah PKS, dipasarkan langsung kepada para konsumen yaitu para calon pemilih di pemilu. Komunikasi ini dilakukan oleh para kader PKS kepada para calon pemilih secara langsung. Direct selling ini adalah metode yang dimiliki oleh DPD PKS Jakarta Timur, tetapi kemudian diadopsi oleh DPP PKS dan disebarkan ke seluruh Indonesia. Ada sekitar 5000 kader atau simpatisan DPD PKS Jakarta Timur yang 
disebar untuk melakukan direct selling, setiap kader atau simpatisan memiliki target 100 orang, sehingga ada sekitar 500.000 target yang didatangi dan mendapatkan sosialisasi mengenai PKS.

\section{Pengunaan Media Pada Saat Kampanye}

Menurut Nimmo (2004) Komunikasi Masa bisa menggunakan media elektronik dan media cetak. Hal ini dilakukan DPD PKS Jakarta Timur, melalui media elektronik PKS memasang Iklan di radio dan televisi. Penayangan iklan berlangsung mulai 11 Maret-1 April 2004. Selain dalam bentuk iklan PKS juga mengeluarkan film documenter melalui VCD yang disebar ke berbagai pihak. Penggunaan internet juga dilakukan melalui website WWW.PKS-Jaktim.or.id. Menurut Zulkifli AS Selain media elektronik pihak DPD PKS Jakarta Timur mengunakan media cetak dalam menyebarkan pesan-pesan antara lain atribut partai, sticker, brosur, spanduk, majalah, buku. Media -media ceak ini disebar ke seluruh masyarakat yang ada di Jakarta Timur.

\section{KESIMPULAN}

Implikasi Teori dari penelitian ini bahwa teori komunikator yang dikemukakan oleh Nimmo terbukti dalam pnelitian ini, dimana komunikator efektif dalam kampanye, karena memiliki status, kredibilitas, daya tarik yang baik. Sedangkan teori mengenai pesan yang dikemukakan Wilburrm Scram berlaku juga dalam penelitian ini, bahwa pesan yang baik adalah pesan yang sesuai kebutuhan masyarakat dan dirancangkan dan disampaikan secara baik sehingga dapat menarik perhatian sasaran. Keberhasilan kampanye PKS Jakarta Timur di tunjang beberapa cara, menurut Roger \& Storey, Rice \& Atkin, dan Imawan, untuk menunjang keberhasilan kampanye, seperti melakukan komunikasi interpersonal, segmentasi pesan, dan pawai di jalan.

\section{REFERENSI}

Berry, H., \& Waluyo, S. (2005). Kebangkitan Politik Dakwah, Konsep dan Praktik Politik Partai Keadilan Sejahtera di Masa Transisi. Bandung: Harakatuna Publishing.

Corbett, W. J. (1989). Tehniques of Internal Communication. Melbourne: Longman Profesional, Ltd.

Creswell, J. W., \& Creswell, J. D. (2017). Research Design: Qualitative, Quantitative, and Mixed Methods Approaches. Sage publications.

Doob, L. W. (1971). Communication in Africa. The Rhetoric of Nonverbal Communication: Readings, 68-71.

Effendy, O. U. (1986). Dinamika komunikasi. Bandung: CV. Remadja Karya.

Huntington, S. P., Marjohan, A., \& Abadi, A. S. (1995). Gelombang Demokratisasi Ketiga. Jakarta: Pustaka Utama Grafiti.

Imawan, R. (1997). Membedah Politik Orde Baru. Yogyakarta: Pustaka Pelajar.

Kusumarasri, A. P., Pradekso, T., \& Ulfa, N. S. (2013). Hubungan antara Tingkat Pendidikan dan Tingkat Pemahaman Pesan Kampanye Sosial Light On dengan Perilaku Menyalakan Lampu Utama Sepeda Motor. Interaksi Online, 1(3), 119. 
Meyer, T. (2003). Demokrasi: Sebuah Pengantar untuk Penerapan. Jakarta: Kantor Perwakilan Friedrich-Ebert-Stiftung (FES).

Nimmo, D. (2004). Komunikasi Politik Komunikator, Pesan, Media. Bandung: Remaja Rodakarya.

Rauf, M. (2001). Konsensus dan Konflik Politik. Jakarta: Direktorat Jendral Pendidikan Tinggi Departemen Pendidikan Nasional.

Rice, R. E., \& Atkin, C. K. (2012). Public Communication Campaigns. Los Angeles: SAGE publications.

Rogers, E. M., \& Storey, J. D. (1987). Communication Campaign. Handbook of Communication Science. New Burry Park, CA: SAGE.

Schramm, W. (1955). Information theory and mass communication. Journalism Quarterly, 32(2), 131-146.

Venus, A. (2004). Manajemen Kampanye: Panduan Teoritis dan Praktis dalam Mengefektifkan Kampanye Komunikasi. Bandung. Simbiosa Rekatama Media. 